\title{
Customers' Expectations and Perceptions of Service Quality: The Case of a Retail Pharmacy Chain in South Africa
}

\author{
Nafisa Adat \\ Student, Department of Marketing and Retail Management, Durban University of Technology \\ Email: nafisaa@dut.ac.za \\ Dion T Noel \\ Lecturer, Department of Marketing and Retail Management, Durban University of Technology \\ Email:dionn@dut.ac.za
}

(Darry) S Penceliah*

Adjunct Professor, Department of Marketing and Retail Management, Durban University of Technology Email: pencelid@dut.ac.za

\section{Doi:10.5901/mjss.2014.v5n20p2648}

Abstract

Recent legislative changes have permitted rapid expansion of pharmacy chains in South Africa. The early effect of this appears to be lowered prices and greater competition amongst pharmacy chains. Whilst research has been conducted on general aspects of customer service quality in various industries, there appears to be few studies on customer satisfaction within the South African retail pharmaceutical sector in particular. This paper therefore seeks to assess customer satisfaction at a selected pharmacy chain within the greater Durban area. A study was conducted among 400 customers, using the SERVQUAL model as the measuring instrument. The results indicate that there are gaps between customers' expectations and perceptions on the five service quality dimensions. The chi square test was performed to determine significant differences between four biographical variables viz. gender, age, educational level of respondents and frequency of shopping versus the five dimensions of service quality, on both expectations and perceptions. Recommendations are presented on how the pharmacy chain can enhance service quality in order to offer superior customer service in the face of growing competition.

Keywords: service quality, pharmacy chain, expectations, perceptions, Servqual

\section{Introduction}

South Africa has the largest economy and the most regulated pharmaceutical industry on the continent (Lowe and Montagu, 2009). All of the major pharmaceutical companies are represented, alongside strong local players, and the market is also attracting strong interest from newcomers, particularly Indian generics companies looking to expand outside of their home territory. There are big changes occurring at the dispensing- end led by retail pharmacy chains such as Clicks and Dis-chem (Lawrence and Ortelli, 2009). Corporate pharmacies are expected to increase their market share at the expense of independents (Laschinger, 2006). Given these dynamics, it has become more important for retail pharmacies to identify customer values and demands. In order to realize customer demands, service quality is a critical factor that retail pharmacies need to focus on (Jain, Sinha and Sahney, 2011). Hence, service quality should be seen as paramount to gain competitive advantage in this competitive pharmaceutical sector. Having an understanding of the competition that exists in this sector, research into the measurement of service quality becomes justified. Dehghan, Zenouzi and Albadvi (2012) state that the starting point in developing quality in services is analysis and measurement. This paper therefore aims to examine the expectations and perceptions of customers with regards to service quality. Specifically, it seeks to identify gaps between expectations and perceptions of service quality, and to examine relationships between selected biographical variables and customers' expectations and perceptions of service quality. The study focuses on one retail pharmacy chain in South Africa but will be of interest to other retail pharmacy chains, both in South Africa as well as other developing countries. Furthermore, the study outcomes will assist management in realizing service quality gaps and improving on overall service delivery. Ultimately, it is envisaged that this research will 
assist both government and business in trying to improve the economic climate within the South African retail sector.

\section{Literature Review}

This section looks at retail pharmacy services in South Africa, the meaning of service quality, dimension of service quality, service quality and customer satisfaction.

\subsection{Retail pharmacy services in South Africa}

According to Lawrence and Ortelli (2009), South Africa is aiming to take its pharmaceutical sector to the next level. All major pharmaceutical companies are represented and the market is also attracting strong interest from Indian generics companies looking to expand outside of their home territory (Lowe and Montagu, 2009). Market consolidation through shared ownership, franchise arrangements or formal collaboration is usually impeded by ownership laws. Consolidation in South Africa has resulted from a recent legislative change in 2003 that permits corporate ownership of pharmacies for the first time (Lowe and Montagu, 2009). This has resulted in big changes occurring at the dispensing- end led by retail pharmacy chains such as Clicks and Dis-chem. The Clicks group has over 283 dispensaries and is adding additional services such as screening and basic health care in some of its stores (Clicks Pharmacy, 2013). Pick n' Pay also has 24 clinics in their stores providing full pharmacy services (Lowe and Montagu, 2009). Shoprite Checkers Medi-Rite pharmacies have expanded to 129 branches nationwide (MediRite, 2013). Lowe and Montagu (2009) state that in the first four years after ownership deregulation, the total number of pharmacies in South Africa has increased by $15 \%$. Hence, customer satisfaction should be seen as paramount to gain competitive advantage in this competitive market sector.

\subsection{The meaning of service quality}

Service quality is one of the most important and widely researched topics in services (Carrillat, Jaramillo and Mulki, 2009). Ladhari (2009) states that service quality, per se, is difficult to define and measure and has been widely debated over the last twenty years. There are a number of different "definitions" as to what is meant by service quality. One that is commonly used defines service quality as the extent to which a service meets customers' needs or expectations (Lewis, 2010). Service quality can thus be defined as the difference between customer expectations of service and perceived service. If perceived service matches or exceeds customer expectations, the customer is satisfied with the service delivery (Lovelock and Wright, 2007). However, if expectations are greater than performance, then perceived quality is less than satisfactory and hence customer dissatisfaction occurs (Dehghan, Zenouzi and Albadvi, 2012). Padma, Rajendran and Sai (2009) state that because services are performances, they cannot be stored, saved, resold or returned. These characteristics make the process of service purchase and delivery very complex for both customer and seller (Vibha, Ravichandran and Jain, 2011). Javadi and Gol (2011) suggest that in reducing uncertainty, buyers seek certain conclusions of service quality from the place, personnel, equipment, and communications they receive from the service provider. The basis for measurement of service quality in this study is the SERVQUAL model which measures service quality based on five dimensions and is briefly covered in the sections that follow.

\subsection{The dimensions of service quality}

According to Zeithaml, Bitner and Gremler (2006), five factors that impact on the quality of service delivery include tangibles, reliability, responsiveness, assurance and empathy and are discussed below:

Tangibles: These are physical representations of the service. Brink and Berndt (2010), define tangibles as the appearance of physical facilities and equipment, the personnel, and the communication devices existing in service organisations. The challenge for retail pharmacy chains is to ensure that these tangible cues meet the expectations of their customers consistently. Finally, it is important to show the link between service quality and customer satisfaction.

Reliability: Reliability is defined as the ability to perform the promised service dependably and accurately (Dehghan, Zenouzi and Albadvi, 2012). Furthermore, reliability refers to the ability to do and provide the promised services in an appropriate, accurate and reliable manner, doing what is expected by the customer (Javadi and Gol, 2011). Within the retail pharmacy chain context, this relates to ensuring that prescriptions are ready for collection and medication is always available. Reliability is regarded as the most important dimension of service quality (Chowdhary and Prakash, 2007).

Responsiveness: Zeithaml, Bitner and Gremler (2006) state that this dimension emphasises attentiveness as well 
as promptness in handling customer questions, complaints, requests and problems. It also refers to the ability to develop customised solutions for customers. In a retail pharmacy context, this includes providing advice and prompt service to medically-related questions and also responding to the changing needs of customers, for example, extending trading hours in response to customer requests.

Assurance: The assurance dimension focuses on the ability of staff to inspire confidence and trust. This refers to the degree of confidence and trust that the retail pharmacy chain is able to engender in the customer, based on the interactions between the parties (Chowdhary and Prakash, 2007). In a retail pharmacy chain context, the main source of assurance is with the pharmacist, nurse or pharmacy personnel. Their knowledge and manner of interaction with the customer should inspire trust in the organization. In addition, it is also expected that the ability to show credibility and courtesy play an important role in the process (Ramsaran-Fowdar, 2008).

Empathy: Empathy refers to the extent to which caring individualised service is given (Javadi and Gol, 2011). In the case of the selected retail pharmacy chain, this is seen in the interactions between the organisation and the customer, and the nature of this interaction. An example of individualized service would be each customer's personal medical details and prescriptions being recorded on a database making the customer feel special.

\subsection{Service quality and customer satisfaction}

Service marketing literature indicates that service quality is an antecedent of customer satisfaction. Dehghan, Zenouzi and Albadvi (2012) state that service quality and its dimensions have a direct bearing on customers' evaluation of a company. These authors stress that all elements of service quality directly influence satisfaction of customers and value the service offers to them. Out of the outcomes that better service offers, customers' satisfaction is said to be the pioneer one. The implications of the research findings regarding the relationship between service quality and customer satisfaction are huge. Businesses need to ensure that the customer perceptions of service quality are consistently higher than their expectations so that customers remain satisfied. This will ensure greater profitability for the business and stronger market competitiveness (Chau and Kao, 2009).

\section{Research Methodology}

The study was descriptive, cross sectional and quantitative in nature. The SERVQUAL instrument, pioneered by Parasuraman, Zeithaml and Berry (1985) was used to measure respondents' expectation and perception of service quality, using 44 items that cover the five dimensions of service quality identified in the literature review. A five-point Likert scale (strongly disagree - strongly agree) was used. For the purposes of this study, the total number of respondents who participated was 400 as this sample size is believed to be large enough given the purpose and goals of the study (Sekaran and Bougie, 2010). Four shopping malls selected for the purposes of this study included Gateway, Musgrave, Pavilion and City View respectively as these malls represented customers from varied socio-economic backgrounds within the Greater Durban area. The researcher further believes that these malls provided a cross-spectrum of customers who fall within varied demographic categories of age, gender and educational levels. 100 respondents were chosen at each store on the basis of convenience sampling. The questionnaires were personally administered with the use of fieldwork assistants. The data was analysed using the SPSS statistical package (Version 20). Reliability was assessed by means of Cronbach Alpha.

\section{Findings and Discussion}

\subsection{Biographical characteristics of respondents}

Gender of respondents per location: As reflected in Figure 1, the overall pattern indicates that there were more female respondents per location than male respondents. The levels of female respondents were fairly similar for Musgrave and Pavilion (69\% and 66\% respectively), as well as for City View and Gateway with $57.6 \%$ and $60 \%$ respectively. Overall, the gender composition of females to males was $63.2 \%$ to $36.8 \%$ female to male respondents indicating that women were the predominant shoppers. This could be attributed to women buying products for the entire household. Demographic characteristics such as gender, age, education, and income have significant effects on perceptions of shopping experiences and can help businesses develop more accurate profiles of their intended consumer base (Hasan, 2010). 
Figure 1: Gender of respondents per location

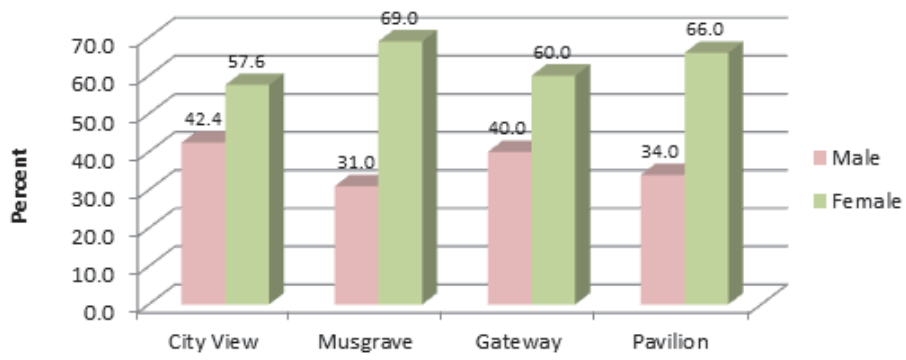

Age of respondents per location: As indicated in Figure 2, the most frequent age group was the 26 to 35 year old age category at all locations. This age group constituted $37 \%$ of the total respondents at City View, $35 \%$ of the respondents at Musgrave, $34 \%$ of the respondents at Gateway and $27 \%$ of the respondents at Pavilion. On average, this grouping constituted nearly one-third of the respondents at each location indicating that the pharmacy chain has quite a young clientele at these stores on average. These findings concur with studies done by Singh and Sahay (2012) which also revealed a young profile of respondents at shopping malls in India.

Figure 2: Age of respondents per location

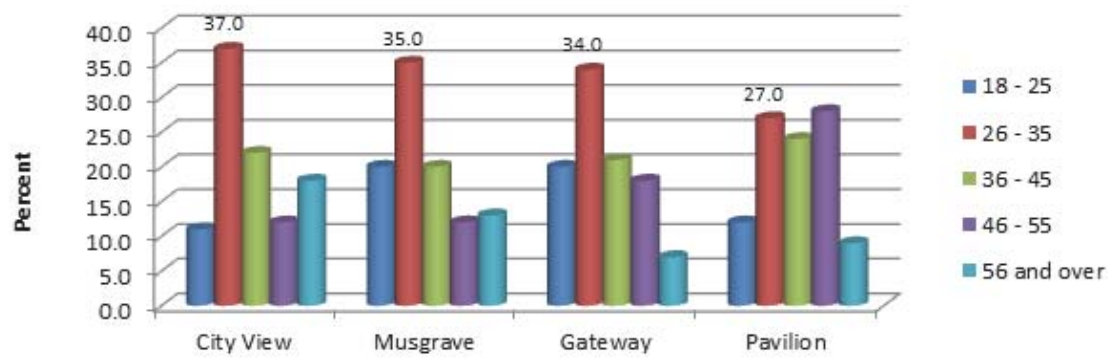

Cross-tabulation of the respondents' age and gender: It emerged that $33.1 \%$ of the respondents were in the 26 to 35 year old age category and were the most frequent age group. Within this age category, $12.3 \%$ of the respondents were male and $20.8 \%$ were female indicating that there were predominantly female shoppers within this age group. The results are reflected in Table 1.

Table 1: Cross-tabulation of the respondents' age and gender

\begin{tabular}{|c|c|c|c|c|c|}
\hline & & & & & Total \\
\hline & & & Male & Female & \\
\hline Age & $18-25$ & Count & 31 & 32 & 63 \\
\hline & & $\%$ of Total & $7.8 \%$ & $8.0 \%$ & $15.8 \%$ \\
\hline & $26-35$ & Count & 49 & 83 & 132 \\
\hline & & $\%$ of Total & $12.3 \%$ & $20.8 \%$ & $33.1 \%$ \\
\hline & $36-45$ & Count & 31 & 56 & 87 \\
\hline & & $\%$ of Total & $7.8 \%$ & $14.0 \%$ & $21.8 \%$ \\
\hline & $46-55$ & Count & 19 & 51 & 70 \\
\hline & & $\%$ of Total & $4.8 \%$ & $12.8 \%$ & $17.5 \%$ \\
\hline & 56 and over & Count & 17 & 30 & 47 \\
\hline & & $\%$ of Total & $4.3 \%$ & $7.5 \%$ & $11.8 \%$ \\
\hline Total & & Count & 147 & 252 & 399 \\
\hline & & $\%$ of Total & $36.8 \%$ & $63.2 \%$ & $100.0 \%$ \\
\hline
\end{tabular}


Educational levels of respondents per location: The results in Figure 3 show that $47 \%$ of the respondents at Gateway had a post-graduate qualification, followed by $45 \%$ at Musgrave, $43 \%$ at Pavilion and $25 \%$ at City View. This finding implies that location of the store does have an impact on the educational patterns of customers.

Figure 3: Educational levels of respondents per location

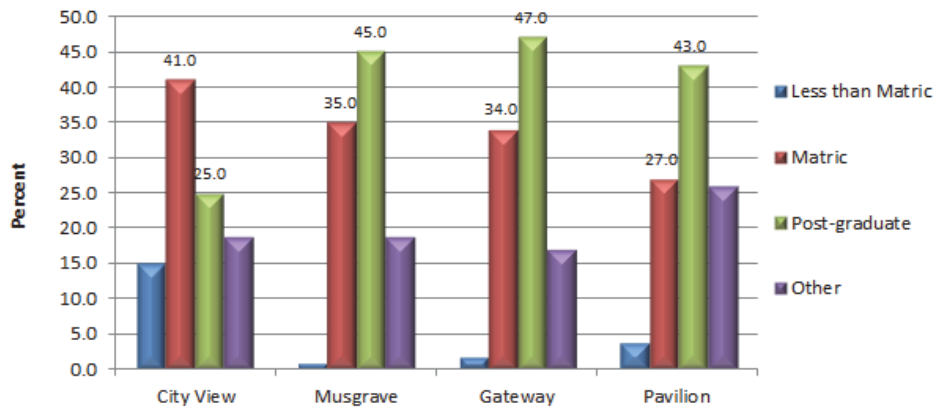

Frequency of shopping per location: As indicated in Figure 4, 52\% of respondents at Musgrave indicated that they shop thrice or more in a month, followed by $50 \%$ at Pavilion and $45 \%$ at Gateway respectively. This finding implies that location of the store does have an impact on the frequency of shopping. The findings by Clottey, Collier and Stodnick (2008) indicate that consumers, who frequently shop, are more favourably inclined toward that specific store and its merchandise quality.

Figure 4: Frequency of shopping per location per month

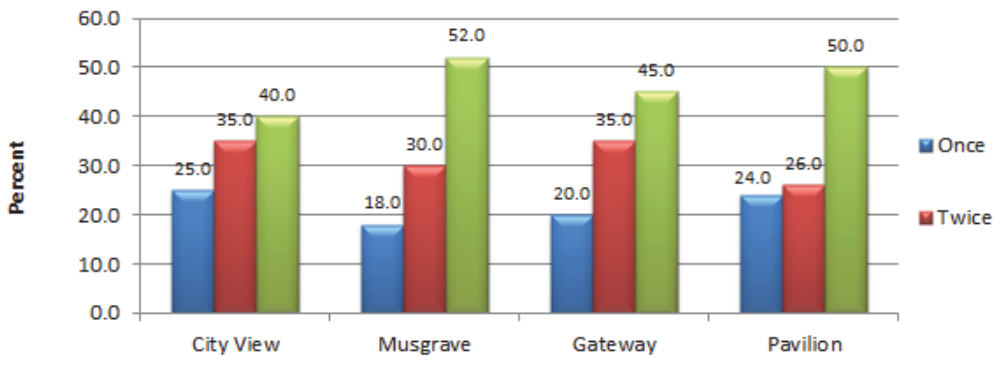

\subsection{SERVQUAL Gap Scores}

Table 2 reflects the scores per service quality dimension for both expectations and perceptions. The responsiveness dimension reflects the highest gap score $(-0.22)$ implying that it needs to be accorded the highest priority with regard to the improvement of service quality, followed by reliability, empathy and assurance, with tangibles having the lowest gap score. The mean GAP score of -0.17 indicates that the perceptions of respondents did not meet with their expectations of overall service quality at the pharmacy chain. Javadi and Gol (2011) state that keeping the customer waiting will result in a customer's dissatisfaction and negative perception of service quality.

Table 2: SERVQUAL GAP Scores

\begin{tabular}{lccc}
\hline Dimension & Expectation $(\mathbf{E})$ & Perception $(\mathbf{P})$ & Score (P-E) \\
\hline Tangibles & 4.27 & 4.17 & -0.1 \\
Reliability & 4.48 & 4.29 & -0.19 \\
Responsiveness & 4.48 & 4.26 & -0.22 \\
Assurance & 4.54 & 4.34 & -0.2 \\
Empathy & 4.49 & 4.32 & -0.16 \\
Overall & 4.45 & 4.28 & -0.17
\end{tabular}




\subsection{Chi-square test}

Table 3 reflects the results of the chi square test used to determine whether there was any relationship between the biographical factors and each of the service quality statements. The results indicate a significant difference in the scores for gender, age, qualification and frequency at the 95\% level $(p<0.05)$. The $p$-value between "Staff at an excellent pharmacy should understand customers' specific needs_P" and "Frequency" was 0.042 which implies that the number of times respondents visited pharmacies did play a role in terms of how they perceived staff understanding customers' needs. Gender and the expectation of staff being courteous were also inter-related with the $p$-value at 0.020 . This result indicated that respondents' gender did play a role in terms of how they expected staff to be consistently courteous. These results are reflected in Table 3.

Table 3: Chi- Square test

\begin{tabular}{|c|c|c|c|c|}
\hline & Gender & Age & Qualification & Frequency \\
\hline Excellent pharmacies should have modern looking equipment_E & 0.908 & 0.121 & 0.36 & 0.295 \\
\hline The physical facilities at an excellent pharmacy should be visually appealing_E & 0.524 & 0.404 & 0.412 & 0.17 \\
\hline Employees at an excellent pharmacy should be neat in appearance_E & 0.347 & 0.526 & 0.563 & 0.178 \\
\hline Advertising material should be visually appealing at an excellent pharmacy_E & 0.621 & 0.067 & 0.659 & 0.884 \\
\hline When excellent pharmacies promise to do something by a certain time, they should do so_E & 0.523 & $.012^{*}$ & 0.236 & 0.333 \\
\hline When you have a problem, excellent pharmacies should show a sincere interest in solving it_E & 0.281 & 0.056 & 0.786 & 0.555 \\
\hline Employees at an excellent pharmacy should perform the service right the first time_E & 0.614 & 0.14 & 0.843 & 0.143 \\
\hline Excellent pharmacies should deliver its services at the times it promises to do so_E & 0.101 & 0.599 & 0.916 & 0.119 \\
\hline The staff should inform me about when services will be performed_E & 0.394 & 0.9 & 0.777 & 0.58 \\
\hline Excellent pharmacies should insist on error-free records_E & 0.422 & 0.531 & 0.185 & 0.6 \\
\hline Employees at an excellent pharmacy should give you prompt service_E & 0.179 & 0.062 & 0.983 & 0.417 \\
\hline Employees should always be willing to help you at an excellent pharmacy_E & 0.784 & 0.269 & 0.943 & 0.697 \\
\hline $\begin{array}{l}\text { Employees at an excellent pharmacy should never be too busy to respond to customer } \\
\text { requests_E }\end{array}$ & 0.85 & 0.163 & 0.814 & 0.441 \\
\hline The behaviour of employees should instil confidence in you_E & 0.303 & 0.07 & 0.839 & 0.188 \\
\hline You should feel safe in your transactions with an excellent pharmacy_E & 0.662 & 0.888 & 0.308 & 0.176 \\
\hline Employees at an excellent pharmacy should consistently be courteous to customers_E & $.020^{*}$ & 0.638 & 0.475 & 0.069 \\
\hline Staff should have the professional knowledge to answer your questions_E & 0.247 & 0.254 & 0.74 & 0.837 \\
\hline Staff should give personal attention to customers_E & 0.272 & 0.057 & 0.634 & $.033^{*}$ \\
\hline Excellent pharmacies should have the customers best interests at heart_E & 0.215 & 0.469 & 0.131 & $.011^{*}$ \\
\hline Staff at an excellent pharmacy should understand customers' specific needs_E & 0.6 & 0.069 & 0.432 & 0.162 \\
\hline Employees at an excellent pharmacy should give you personal attention_E & 0.976 & 0.14 & 0.44 & 0.28 \\
\hline Excellent pharmacies should have convenient business hours_E & 0.804 & 0.09 & 0.384 & 0.169 \\
\hline Excellent pharmacies should have modern looking equipment_P & 0.833 & 0.183 & 0.16 & 0.235 \\
\hline The physical facilities at an excellent pharmacy should be visually appealing_P & 0.161 & 0.263 & 0.724 & $.028^{*}$ \\
\hline Employees at an excellent pharmacy should be neat in appearance_P & 0.338 & 0.099 & 0.721 & 0.086 \\
\hline Advertising material should be visually appealing at an excellent pharmacy_P & 0.554 & 0.053 & 0.346 & 0.267 \\
\hline When excellent pharmacies promise to do something by a certain time, they should do so_P & 0.894 & 0.466 & 0.586 & 0.161 \\
\hline When you have a problem, excellent pharmacies should show a sincere interest in solving it_P & 0.871 & $.042^{*}$ & 0.203 & 0.09 \\
\hline Employees at an excellent pharmacy should perform the service right the first time_P & 0.734 & 0.126 & 0.057 & 0.072 \\
\hline Excellent pharmacies should deliver its services at the times it promises to do so_P & 0.327 & 0.065 & 0.336 & 0.104 \\
\hline The staff should inform me about when services will be performed_P & 0.728 & $.034^{*}$ & 0.452 & 0.099 \\
\hline Excellent pharmacies should insist on error-free records_P & 0.387 & 0.08 & 0.632 & 0.421 \\
\hline Employees at an excellent pharmacy should give you prompt service_P & 0.951 & 0.521 & 0.063 & 0.229 \\
\hline Employees should always be willing to help you at an excellent pharmacy_P & 0.913 & $.008^{*}$ & 0.12 & $.018^{*}$ \\
\hline $\begin{array}{l}\text { Employees at an excellent pharmacy should never be too busy to respond to customer } \\
\text { requests_P }\end{array}$ & 0.984 & $.015^{*}$ & 0.597 & $.003^{*}$ \\
\hline The behaviour of employees should instil confidence in you_P & 0.756 & 0.859 & 0.326 & 0.715 \\
\hline You should feel safe in your transactions with an excellent pharmacy_P & 0.77 & 0.208 & 0.428 & 0.779 \\
\hline Employees at an excellent pharmacy should consistently be courteous to customers_P & 0.641 & $.001^{*}$ & 0.389 & 0.384 \\
\hline Staff should have the professional knowledge to answer your questions_P & 0.833 & 0.274 & 0.38 & 0.062 \\
\hline Staff should give personal attention to customers_P & 0.181 & 0.058 & 0.168 & 0.123 \\
\hline Excellent pharmacies should have the customers best interests at heart_P & 0.307 & 0.266 & 0.327 & 0.52 \\
\hline Staff at an excellent pharmacy should understand customers' specific needs_P & 0.237 & 0.063 & 0.179 & $.042^{*}$ \\
\hline Employees at an excellent pharmacy should give you personal attention_P & 0.886 & 0.26 & 0.48 & 0.703 \\
\hline Excellent pharmacies should have convenient business hours._P & 0.543 & 0.066 & 0.594 & 0.063 \\
\hline
\end{tabular}


From the Chi-square results, further significant findings emerged. The expectation that "Excellent pharmacies should have the customers best interests at heart" and frequency of visit correlated at 0.011 which was less than the level of significance of 0.05 . Hence, the number of times respondents visited the pharmacy chain did play a role in terms of their expectations of staff having the customers' best interests at heart. The frequency of visits also impacted on customers' expectations of staff giving personal attention to customers. A score of 0.033 was realised implying that management of the pharmacy chain need to ensure that staff give customers consistent individualised attention at all times.

Furthermore, the biographical variable of age also played a role in terms of how respondents expect the pharmacy to deliver on its promises. The p-value between "When excellent pharmacies promise to do something by a certain time, they should do so E" and "Age" was 0.012. Also, the p-value between "When you have a problem, excellent pharmacies should show a sincere interest in solving it_P" and "Age" was 0.042 implying that respondents' age did impact on how they perceive the pharmacy showing a sincere interest when a customer has a problem. The above chi-square results highlight the significant correlations between the biographical factors and each of the service quality statements and must be realised by management in terms of continuous improvement. Overall, customer satisfaction at a retail pharmacy is influenced by perceptions of service quality, perceptions of the cost of medication, the efficiency and knowledge of staff as well as the emotional state of the customer (Laschinger, 2006).

\section{Concluding Remarks}

This study sought to assess customer satisfaction at a selected retail pharmacy chain in South Africa. The results indicated that there were gaps in terms of the five dimensions of service quality with the responsiveness dimension showing the largest gap score and the tangibles dimension showing the smallest gap score. It emerged that there were significant differences between gender and the expectation of staff being courteous. Strong correlations between the frequency of shopping and the expectation of giving personal attention to customers were found. There were no significant differences between the educational levels of respondents and the expectations and perception items. Based on the research findings, it is recommended that employees must be trained in service quality-related programmes e.g. communication, interpersonal skills, product knowledge and service improvement with a view to enhancing service quality among customers. This view is shared by Ramsaran-Fowdar (2008) who highlights the importance of inspiring trust and confidence in customers as a very important variable contributing to customer satisfaction. Management must prioritise staff schedules to ensure that sufficient staff is on duty and more counters available to offer customers a prompt service. Management should ensure that appropriate feedback mechanisms are in place to check deadlines promised to customers, carrying out promises timeously as well as dedication shown by staff to solve customers' problems and generally, ensure a customer-centric approach.

\section{References}

Brink, A and Berndt, A. 2010. Customer Relationship Management and Customer Service. Johannesburg: Juta.

Carrillat, F. A., Jaramillo, F. and Mulki, J. P. 2009. Examining the impact of service quality: a meta-analysis of empirical evidence. Journal of Marketing Theory and Practice. 17(2): 95-110.

Chau, V. S. and Kao, Y. Y. 2009. Bridge over troubled water or long and winding road?

Gap-5 in airline service quality performance measures. Managing Service Quality. 19(1): 106-134.

Chowdhary, N. and Prakash, M. 2007. Prioritizing service quality dimensions. Managing Service Quality. 17(5): $493-509$.

Clottey, T., Collier, D. and Stodnick, M. 2008. Drivers of customer loyalty in a retail store environment. Journal of Service Sciences. 1(1): 35-48.

Dehghan , A.; Zenouzi, B. and Albadvi, A. 2012. An investigation on the relationship between service quality and customer satisfaction: in the case of CCG Company. International Business Research. 5(1): 3-8.

Hasan, B. 2010. Exploring gender differences in online shopping attitude. Computers in Human Behavior. 26(4): 597-601.

Jain, R., Sinha, G. \& Sahney, S. 2011. Conceptualising service quality in higher education.

Asian Journal on Quality, 12(3), 296-314.

Javadi, M. H. and Gol, R. 2011. Service quality evaluation in general department of health insurance of Fars Province using a Servqual model (case study: Shiraz). Interdisciplinary Journal of Contemporary Research in Business. 3(4): 118-125.

Ladhari, R. 2009. A review of twenty years of Servqual research. International Journal of Quality and Service Sciences. 1(2): 172-198.

Laschinger, K. 2006. Kneale to delight new Clicks customers. Finweek, (February 9): 32- 33.

Lawrence, T. and Ortelli, M. 2009. The rainbow nation: South Africa's spectrum of opportunities. Pharmaceutical Technology. 33(5): 8489.

Lewis, A. 2010. Service quality model evaluation. Journal of Transport logistics. 34: 235- 254.

Lovelock, C. \& Wright, L. 2007. Principles of Service Marketing and Management. 5th ed. Englewood Cliffs NJ: Pearson. 
Lowe, R. F. and Montagu, D. 2009. Legislation, regulation, and consolidation in the retail pharmacy sector in low income countries. Southern Med Review. 2(2): 35-44.

Padma, P., Rajendran, C. and Sai, L. 2009. A conceptual framework of service quality in healthcare. Benchmark: International Journal. 16(2): 157-191.

Parasuraman, A., Zeithaml, V. A. and Berry, L. L. 1985. A conceptual model of service quality and the implications for future research. Journal of Marketing. 49: 41-50.

Ramsaran-Fowdar, R. 2008. The relative importance of service dimensions in a healthcare setting. International journal of healthcare quality assurance. 21(1): 104-124.

Sam, J. G. 2011. Modeling the optimization of service quality for Indian food retail stores by prioritized service attributes - a non-linear programming approach. Advances in Management. 4(11): 41-51.

Sekaran, U and Bougie, R. 2010. Research Methods for business: A skill-building approach. $5^{\text {th }}$ ed. Chichester: Wiley.

Singh, H. and Sahay, V. 2012. Determinants of shopping experience: Exploring the mall shoppers of national capital region (NCR) of India. International Journal of Retail and Distribution Management. 40(3): 235-248.

Vibha, A., Ravichandran, N. and Jain N. K. 2011. Dimensionality of service quality and its critical predictors to customer satisfaction in Indian retail banking. Advances in Management. 4(10): 20-25.

Zeithaml, V. A., Bitner, M. J. and Gremler, D. 2006. Services Marketing: Integrating Customer Focus Across the Firm. $4^{\text {th }}$ ed. New York: McGraw-Hill. 